\title{
VOLTAIRE E A SÁTIRA ${ }^{1}$
}

Roberto ROMANO ${ }^{2}$

- RESUMO: O texto salienta a importância da sátira lucianesca no pensamento das Luzes, em especial nos textos de Voltaire. Ao mesmo tempo, ele busca criticar a carência de humor na filosofia de nossa época, a partir de uma análise comparativa da prosa iluminista com a fala sibilina das correntes filosóficas irracionalistas, em especial as de Martin Heidegger e de seus epígonos.

- PALAVRAS-CHAVE: Sátira; humor; razão; empírico e transcendental.

Há trezentos anos um filósofo ajudou a mudar a face do mundo provocando polêmica e riso. Não sabemos qual meio foi mais eficaz na guerrilha empreendida por Voltaire contra a sandice religiosa, política, intelectual de seu tempo. O riso é suspeito e tem má fama entre os pensadores do século XVII, menos na escrita de Pascal. Mas Espinosa e Hobbes, para definir apenas dois nomes célebres, restringiram os limites da razão humorística. Conhecemos as teses espinosanas sobre o assunto e

1 Dispensei o uso de notas explicativas ao pé da página, dado o caráter do texto, mais uma reivindicação sobre a seriedade do riso voltaireano, do que um estudo técnico nos moldes habituais. Dado o caráter universal e graças à ampla divulgação das edições de outros autores citados, eles não foram postos do modo costumeiro, com citação completa. Caso ocorra alguma dúvida, o autor poderá indicar tais edições. Este procedimento pesaria, no meu entender, inutilmente, na leitura do presente ensaio.

2 Departamento de Filosofia - Unicamp - Campinas - SP - Brasil. 
recordamos a prudência exibida pelo teórico na distinção entre riso e caçoada. Apenas enquanto momento, citemos o Pequeno tratado sobre Deus e o homem, e sobre sua condição feliz. A caçoada manifesta a imperfeição de quem a usa. Sua base é a falsa opinião de que o sujeito do qual se escarnece é causa de seus atos, esquecendo que tudo o que ele faz vem, necessariamente, de Deus. E, pensando melhor, acrescenta Espinosa, se ridicularizamos alguém, é porque sabemos que ele não merece as nossas gargalhadas. Neste caso, somos canalhas, ou, na língua eminente do pensador, temos uma natureza ruim. No polo inverso, caso o indivíduo mereça nossos acicates, os seus defeitos deveriam ser corrigidos com bons argumentos, e não por meio de caçoadas.

Riso e zombaria distinguem-se: o primeiro pertence ao homem que encontra algo bom em si mesmo. O riso expressa alegria. Quando verdadeiro, ele nasce de uma idéia e asssume a forma intelectual, não se originando mais nos movimentos apaixonados. Na Ética encontra-se a tese de que a caçoada nasce do desprezo de algo amado ou temido (Primeira Parte, Proposição 52, Escólio). Escárnio e ódio aproximam-se: a caçoada é alegria nascida de nossa imaginação, quando dizemos existir algo desprezível no que odiamos. Já o riso que brota da idéia, como a brincadeira, é uma alegria pura. "Apenas uma triste superstição", diz Espinosa, "proíbe o deleite". Entre alimentar-nos e expulsar a melancolia, não sabemos qual tarefa é mais importante. O riso expande nosso corpo e aumenta sua potência. Deste modo, ele manifesta a força divina em nós. Aliás, arremata Espinosa, "nenhum deus, ou uma outra pessoa, a não ser o invejoso, se alegra com nossa impotência e dor, vendo como virtude nossas lágrimas, gemidos, medo etc., os quais constituem o signo de uma alma impotente. Quanto mais nos afeta uma pura alegria, mais passamos a uma perfeição maior, mais é necessário que participemos da natureza divina" ("De servitude humana", Ética, Quarta Parte, Proposição 45, Escólio).

Com o intelecto, Espinosa indica os elementos teóricos do existir prazeroso. Apenas a superstição é triste. Só ela se compraz em lágrimas e despreza o mundo. Ela não ri, mas caçoa do homem. Os supersticiosos e adeptos da separação entre Deus e os homens apontam os sentimentos dos últimos como defeitos, aos quais eles sucumbiriam por "livre arbítrio". Quem assim pensa, lamenta o nosso destino, ou caçoa dos indivíduos. Seu ódio chega até a maldição. A resultante filosofia normativa estatui uma natureza humana fictícia que despreza os homens tal como eles são efetivamente. Ela, deste modo, não escreve "uma ética, mas uma sátira" (Tratado político).

Na luta contra a superstição, o reino das trevas, Hobbes também se empenhou no combate à caçoada, confundida erroneamente com a alegria. Quem está satisfeito consigo mesmo tem segurança. Mas se tal gló- 
ria chega de uma opinião errônea, ou se deriva da lisonja, o indivíduo é presa da vanglória. No mesmo campo, vem a caçoada. Esta é glorificação súbita, uma paixão que produz as distorções da face às quais denominamos riso, que nasce quando percebemos nos outros alguma desgraça e aplaudimos a nós mesmos. Semelhante paixão domina sobretudo os que têm consciência de possuir menores aptidões, e que são obrigados, se querem continuar estimando a si mesmos, a dirigir os dedos para os defeitos alheios. Por isto, rir muito das falhas dos outros significa estreiteza de espírito. Uma tarefa própria às grandes almas é livrar os demais do desprezo e de se comparar apenas aos melhores.

Decoramos essas passagens do Leviatã. Mas poucos dentre nós aquilatam sua importância antropológica e política. Gostaria de indicar que o trecho cita indiretamente Plutarco, num dos seus tratados morais importantíssimos para a ética ocidental. Refiro-me ao De curiositate, cuja presença detectamos ao longo do Renascimento e durante toda a modernidade. Sem este tratado torna-se ininteligível, por exemplo, o parágrafo 36 do heideggeriano Ser e tempo. Como também é absolutamente sem sentido o parágrafo anterior, o 35 , arrancado de outro livro de Plutarco, o De garrulitate. Heidegger não costuma citar seus autores, ou prefere citá-los de modo insinuante. Mas todo estudioso que se der ao trabalho de ler, de maneira sinótica, os conjuntos textuais, constatará esta dependência de nosso contemporâneo ante o filósofo antigo. Mas voltemos ao nexo entre Hobbes e Plutarco. Só a tolice e a lisonja (faces do mesmo fenômeno) podem nos fazer imaginariamente superiores aos demais homens. Acrescentemos aos dois textos de Plutarco mencionados, um terceiro, o De como distinguir o amigo do adulador. Quando falamos muito sobre nós mesmos, e nos interessamos pela desgraça alheia para ressaltar nossa pretensa eminência, somos vítimas da caçoada. Rimos do próximo, num primeiro instante, mas terminamos nas bocas e línguas dos muitos, afastando-nos dos melhores. Quem ri com a populaça, diríamos, termina perdendo a oportunidade única de estar entre os melhores. Se espiamos os defeitos de nossos amigos ou inimigos, é porque partilhamos as suas paixões.

Além de Plutarco, Hobbes conheceu muito bem autores como Luciano de Samosata, por ele utilizado no Leviatã. Um livro fascinante, no plano da apropriação da retórica ligada ao riso, foi escrito recentemente por Quentin Skinner. Nele, fica bem claro que a atitude hobbesiana, voltada contra o riso, não é algo certo. Pelo contrário, Skinner mostra, com bastante clareza, o quanto nosso filósofo utilizou a técnica satírica para desarmar os seus adversários, sobretudo a Igreja Católica.

A curiosidade, afirma Plutarco, mostra o desejo de saber o que vai mal na casa dos outros. Esta doença é cheia de inveja e maldade. Com 
ela, fugimos ao preceito délfico, o conhece-te a ti mesmo. Os atacados pela curiosidade, afirmam Plutarco, Hobbes, Heidegger, procuram ver o que se passa fora de sua casa. "A constituição fundamental da vista manifesta-se numa tendência ontológica particular que empurra nosso ser cotidiano para o "ver"' (Ser e tempo, § 36). Plutarco é mais poético: o curioso é como a Lâmia mitológica. "Quando dormia em sua casa, ela depositava os olhos num vaso. Saindo, Lâmia os colocava em seu rosto e podia ver". Assim, "cada um de nós ... põe sua indiscreção em sua maldade como num olho, esquecendo as próprias faltas e taras por ignorância, porque não tem o meio de vê-las e de esclarecê-las" (De curiositate, 2 ).

A curiosidade é a paixão de conhecer o escondido e o dissimulado. Mas ninguém esconde o bem que possui. Às vezes nos atribuímos um bem que não temos. O curioso, em seu desejo de saber o que vai mal entre os demais, é tomado pela paixão da maldade, irmã da inveja e da calúnia. Porque a inveja é a tristeza causada pelo contentamento alheio e a maldade é alegria pela sua infelicidade. Ambas nascem de uma cruel paixão, a ruindade. (Plutarco, 6)

Nesta trilha encontramos a fonte comum da sabedoria ética moderna, de Erasmo a J. J.- Rousseau, passando por Espinosa e Hobbes, chegando até Heidegger. Uma coisa é alegrar-se consigo mesmo, por justos motivos. Esta é glória. Outra, é caçoar do próximo, fugindo do espetáculo pavoroso de nosso próprio interior. Esta é a vanglória. O adulador engana simulando uma face agradável à sua vítima. $\mathrm{O}$ curioso deseja penetrar no íntimo das consciências, destruindo toda dissimulação, toda opacidade, para atingir a miserável nudez alheia. Ele esquece, portanto, que a sua vida é tão mesquinha quanto a dos demais. Todos estes pontos serviram aos que se dedicaram à análise da transparência e dos obstáculos entre os seres.

Não por acaso, nesse conjunto noético encontramos a figura do olhar e da face, anunciando o tema da máscara. Há um poderoso, temível em demasia, diz Elias Canetti, indicando quem sempre está disposto a desmascarar o próximo mas guarda intacta a sua própria persona. É uma forma de domínio covarde que sempre usa a denúncia contra os outros, comprazendo-se em tornar públicas as misérias particulares. Trata-se de uma doença, diz Plutarco, referindo-se ao prazer de prejudicar que move quem gargalha ao ver as tristezas exibidas pela alteridade. "Só um invejoso se alegra com minha impotência", deduz Espinosa. O sujeito de intelecto fraco se alegra com os defeitos do próximo, afiança Hobbes. O curioso, buscando sempre alimentos novos para sua paixão, quer se divertir, assevera Heidegger: "A curiosidade proporciona para si mesma, através desta instabilidade, a constante e possível distração". (Ser e tempo, §36). Divertir-se às expensas alheias é um jogo perigoso, porque não 
deriva do conhecimento racional. Só este último, segundo Espinosa, é riso puro.

Indiquemos a operação meticulosa desenvolvida por Heidegger no texto plutarquiano. Através do elemento comum ao conhecer e à curiosidade, o olhar, nosso hermeneuta desliza as determinações de um campo para o outro. Deste modo, os traços da racionalidade científica, "a preocupação de ver é essencial ao ser do homem, (Aristóteles, Met. A, 1, 980 a 21, citado por Heidegger), passam, segundo Santo Agostinho, pela hipertrofia dos olhos que domina todos os demais sentidos ("olha este som, este odor, este sabor, esta dureza...", Confissões, X, Capítulo 35, também citadas por Heidegger), e atinge, em Plutarco, o domínio das paixões, ou mesmo, da doença: a curiosidade e a parolice. Em Heidegger, o que nos textos plutarquianos devia-se a dois campos diferentes - a razão e a doença - coloca-se num registro único: a curiosidade do olhar, com maior ou menor intensidade e constância. O pensador científico permanece no objeto visto, teorizado melhor dizendo, enquanto o curioso passeia a vista por muitos modos e objetos, sem descanso nem morada.

Ou seja: o filistino curioso do cotidiano possuiria apenas uma diferença de grau ante o cientista. O primeiro seria um adoecido descendente do segundo, um ser que perdeu a força de permanecer olhando o seu alvo. Daí, segue-se a tese irracionalista de que a ciência e a curiosidade malignas são "unum atque idem". Seguidores de Heidegger pioram este processo. Via Santo Agostinho, o próprio Heidegger realiza o deslizamento entre dois campos na filosofia moderna, o plutarquiano - racionalista convicto - e o pascalino. Não por acaso o tema da "distração", extraído de Pascal, e presente no parágrafo 36 de Ser e Tempo, passa por uma leitura que exagera, no próprio Agostinho, o defeito da hipertrofia óptica. A lição de Pascal, o jansenista, subjaz, laicizada, em Heidegger .

O riso era suspeito para os filósofos do século XVII, menos para o piedoso Pascal. Este último não tem ilusões sobre a existência. Embora esteja longe de querer padronizar os humanos pelo que eles deveriam ser, esquecendo o que eles são de fato, Pascal emprega o riso do intelecto contra os defeitos dos seres finitos e movimenta a sátira mais diabólica, nas Pensées e, sobretudo nas Provinciais para vencer os adeptos do caminho errado, em religião ou ética. $\mathrm{Na} 11^{\mathrm{a}}$ das famosas Cartas a um provincial, temos um monumento grave e caçoísta sobre o riso e a moral, o riso e a religião etc.

Os jesuítas queixaram-se da forma usada por Pascal para combatê-los. As cartas, lidas com sede curiosa pelas rodas parisienses, ávidas de toda novidade picante, produziam um efeito de raio devastador na Cia. de Jesus. O juízo de Racine, neste campo, é o melhor. "E o senhor acha que as Provinciais são outra coisa, a não ser comédia? Nesta última se 
movimenta um serviçal pérfido, um burguês pão-duro, um marquês estranho, e tudo o mais no mundo que merece risada. Confesso que o Provincial escolheu melhor os seus personagens: ele foi buscá-los nos conventos e na Sorbonne, introduziu no palco ora os jacobinos, ora os doutores, e sempre os jesuítas. Quantos papéis ele não os obrigou a desempenhar! Certa feita ele conduz ao palco um jesuíta bondoso, depois, um jesuíta pérfido, mas sempre um jesuíta ridículo. $\mathrm{O}$ mundo riu com isto durante algum tempo. O mais grave jansenista teria acreditado trair a verdade se não risse" (La querelle des imaginaires. Pléiade, II, pág. 29).

Sainte-Beuve, no genial monumento à cultura dos séculos XVII e XVIII, realiza uma aproximação estratégica dos tempos, das obras literárias, das políticas. Há homologia, diz ele em Port-Royal (Pleiade, Tomo II, Livro III), entre os panfletos pascalinos e a Sátira Menipéia que surgiu durante a Liga. Também há afinidade entre as Provinciais e o Tartufo. Os panfletos de Pascal reverberam na Carta ao senhor de Beaumont de J.-J. Rousseau.

Ao redor do Estados Gerais facciosos de 1593, houve uma Sátira Menipéia; ao redor das Câmaras reacionárias de 1815 e de 1823, ocorreram as canções vingadoras de Béranger ... ao redor das Assembléias violentas da Sorbonne de 1655-1656, surgiram as Provinciais. Estas fizeram um sucesso arrasador. Como diz um jesuíta: "Nunca os correios tiveram tanto lucro. Exemplares foram enviados para todas as cidades do reino".

As farpas do Pascal anônimo enlouqueceram tanto os intelectuais da Sorbonne quanto os seus irmãos inimigos, os jesuítas. Os primeiros tentaram censurar as cartas, mas a resposta de Pascal foi rápida e dolorida: "Eles julgaram mais apropriado e mais fácil censurar do que partilhar, porque ser-lhes-ia bem mais fácil encontrar monjes censores do que razões". Comenta Sainte-Beuve: "depois de Pascal, ser doutor da Sorbonne tornou-se, para o mundo e para os olhos profanos, um inconveniente, um ridículo". Digamos que Rabelais tinha sido mais cruel para com a Sorbonne. Mas o juízo de Sainte-Beuve tem boas razões. Voltaire, no Século de Luís XIV, afirmara: "o primeiro livro genial que vimos em prosa foi a coletânea das Cartas provinciais de 1654 ... Todas as eloqüências estão nela presentes". É certo, diz ele mais tarde, que as ditas cartas perderam muito de sua ponta cortante depois que os jesuítas foram abolidos, e os objetos de suas disputas foram desprezados. Sainte-Beuve indica uma prova lateral da importância jansenista no trabalho satírico de Voltaire: sabemos que este último jogou o nome Akakia sobre Maupertuis, ridicularizando-o. Pois bem: Akakia era nome importante entre os senhores jansenistas. Trata-se de uma família cujo apelido foi helenizado já no século XVI. 
As Provinciais não incomodaram apenas a Sorbonne e os jesuítas. Elas exigiram, muito tempo depois, no ridículo e grave, sobretudo contra-revolucionário século XIX, muita verve de J. De Maistre, o arquiinimigo das Luzes, da Renascença, da razão moderna. Para De Maistre, ao lado do Mentiroso de Corneille, deveríamos colocar as Mentirosas de Pascal. Além de acicatar os inimigos dos jansenistas, as Provinciais serviram enquanto modelo satírico para Montesquieu nas Cartas persas e ajudaram, como indicado, na armação da Carta ao senhor de Beaumont, escrita por Rousseau.

A $11^{\text {a }}$ Carta, especialmente, é um tratado sério-cômico sobre o riso. O mote tem origem em Tertuliano: "nada é mais próprio à vaidade do que a risada". Comentando esta $11^{\mathrm{a}}$ carta, diz Sainte-Beuve: "ela poderia servir enquanto prefácio do Tartufo". Nela, poder-se-ia afirmar, "Pascal zombou dos jesuítas para toda a eternidade". Os padres da Cia. de Jesus lamentam: o autor das Provinciais não respeita as coisas santas. A diairesis funciona às maravilhas na pena de Pascal. Não se trata de rir do sagrado, mas dos estultos que parolam erroneamente sobre as coisas santas. De um lado, existe o que se deve respeitar. De outro, o dos jesuítas, surge o que se deve escarnecer. Je n'ai pris sujet de rire que de ce qu'il y a de ridicule dans vos livres ... en me moquant de votre morale, j'ai été aussi éloigné de me moquer des choses saintes". Na verdade, exclama Pascal, "il y a bien de la différence entre rire de la religion et rire de ceux qui la profanent par leurs opinions extravagantes.

A escala da gargalhada vai do homem até o próprio Deus. Pascal dá um sentido novo à imagem da vida enquanto teatro, já presente em Platão, Agostinho, Lutero etc. Somos marionetes dos deuses. Não sabemos se nossa existência é tragédia ou comédia. Nós não a vemos no todo. Só os numes celestes podem assistir a nossa representação. Parece que eles riem de nossas pobres almas.

Pascal decide a parada: Deus se riu do homem. Este último é o ridicolosissimo eroe das Pensées. Erro: Deus não riu-se do homem: Deus ri eternamente de todo e qualquer homem. "Se existe um Deus, ele é infinitamente incompreensível, dado que ele não possui partes nem limites, ele não possui nenhuma relação conosco. Somos incapazes de conhecer o que ele é e mesmo que ele é" (Pensées). No riso e no jogo, sempre que ousamos tolamente brincar com Deus, perdemos. Se perdemos, podemos ganhar tudo, desde que este tudo venha apenas com a Graça divina. "Deus", afirma a $11^{\mathrm{a}}$ Provincial, "odeia e despreza os pecadores, até mesmo na hora da morte. Naquele tempo em que seu estado é o mais deplorável e o mais triste, a sabedoria divina unirá zombaria e risada à vingança e ao furor que os condenará aos suplícios eternos: 'In interitu vestro ridebo et subsanabo?' E os santos, agindo com o mesmo espírito, usarão proce- 
der idêntico, porque, segundo David, ao enxergar os malvados punidos, eles tremerão e rirão ao mesmo tempo: 'Videbunt justi et timebunt: et super eum ridebunt'. E Jó fala do mesmo jeito: 'Innocens subsannabit eos"'.

A cosmogênese e a antrogênese, na perspectiva pascalina, ordenam-se sobremodo pelo riso divino. E tal risada é humilhante para o homem. O pecado original é tolice de um ser finito que imaginou poder elevar-se ao Eterno. A explosão risonha nasce justo desta incongruência, a qual, aliás, é colhida pela razão. Deus, ao constatar a burrice humana, falou para si mesmo (é o que lemos nas primeiras linhas da Biblia): "Eis que Adão tornou-se como um de nós: Ecce Adam quasi unus ex nobis".

Trata-se, diz Pascal, de uma ironia por meio da qual Deus beliscava o homem vivamente. Os patriarcas riram, Jó riu, Agostinho riu, toda a Igreja riu e rirá do pecador. Adão não riu, e foi expulso do paraíso por sua tola seriedade. Deus ri eternamente. Os santos riem com ele vendo os danados. Impossível fechar esta $11^{\mathrm{a}}$ Provincial sem um sorriso amarelo nos cantos dos lábios, e sem recordar as duras pontas contra o cristianismo inteiro, grafadas na Genealogia da moral. Nietzsche fala de Tertuliano, o inspirador de Pascal, no [Contra os espetáculos]. Não se alegrem os pagãos com o circo, grita Tertuliano, onde os seguidores de Cristo são comidos pelas feras. Na Eternidade, os santos terão um espetáculo mais grandioso, mais feliz, vendo para sempre os seus inimigos massacrados em torturas inimagináveis. "Que vasto espetáculo então! Como admirarei! Como rirei! Ali rejubilar-me-ei!”. E Nietzsche une Tertuliano e São Tomás de Aquino na mesma, passe o anacronismo, atitude sádica ressentida. No Comentário ao livro das sentenças (IV, L, 2, 4, 4) Tomás de Aquino afirma: "Para que a felicidade dos santos lhes agrade ainda mais, e para que eles agradeçam a Deus mais abundantemente, ele lhes permitiu ver os tormentos dos ímpios". Esta gargalhada, se concordarmos com Nietzsche, exala ressentimento e impotência eternos.

O maior número dos filósofos prefere combater o riso. Varrão, o representante latino da Sátira Menipéia, deu-lhes a marca registrada: "tristes philosophos et severos". Todos estão sujeitos à doença que abate sábios e poderosos, a melancolia. Um dos textos mais cheios de informações sobre esta tristeza é o clássico e bem humorado livro de Robert Burton, The Anatomy of Melancholy (1621). Nele, é constante o apelo aos escritos satíricos, sobretudo os de Luciano de Samosata. Apanhando o lugar comum da estultície humana, Burton penetra no tema do riso e das lágrimas (outro lugar comum, sobretudo após o Renascimento), nas figuras de Heráclito e Demócrito, com um intróito em que recorda o lucianesco Karonte, observador. Utilizando a técnica da anábasis, Luciano eleva Karonte até uma grande altura a partir da qual ele poderia observar todo o 
mundo sincronicamente. Após sua inspeção, Hermes pergunta-lhe o que viu. As cidades parecem, diz Karonte, "colméias, onde cada abelha possui um ferrão, e não fazem nada mais do que ferretear seu vizinho". Abelhas, zangões, todos sofrem a ação da Esperança, do Medo, da Ignorância, do Ódio. Alguns animaizinhos mostram-se cálidos, enquanto outros são apenas solícitos. As cidades são facções onde todos lutam contra todos. "Criaturas loucas", exclama finalmente Karonte, "por que vocês colocam seu coração nestas coisas?".

Nessa passagem de Luciano, Burton acha um bom veio para abordar o riso. Vale a pena seguir a anedota inteira. Hipócrates fora chamado pelo povo de Abdera para saber se Democrito era doido ou não. O médico encontra o filósofo "sentado sob uma árvore, sobre uma pedra, sem usar sapatos, com um livro em seus joelhos, cortando vários animais, na faina de estudá-los". Perguntado sobre a razão deste procedimento, ele responde que cortava os bichinhos para descobrir a causa da loucura e da melancolia. Após ter o médico enaltecido sua atividade e seu modo feliz de viver, Democrito pergunta-lhe por que também ele, Hipócrates, não tinha contentamento. Resposta: devido às doenças, às dívidas, as querelas familiares, as quais nos roubam o tempo. Demócrito riu disto tudo. $\mathrm{O}$ riso deve-se à vaidade humana que busca riqueza, glória, poder. Os indivíduos ferem-se mutuamente, mãe e filha brigam, irmão luta contra irmão etc. Cada um, que possui seu próprio defeito, enxerga apenas o alheio. O glutão aponta o bêbado, e assim por diante. Eles acreditam pertencerem ao registro dos deuses, não se importando com a vida perene, esquecendo que, dada a mutabilidade do mundo, nada neste último é firme e seguro. "Quem está em cima, amanhã estará em baixo". Segue-se uma longa série de malefícios e tolices, os quais produzem o riso. Quando deixou o filósofo, Hipócrates foi interrogado pelo povo. Afinal, Demócrito era louco, ou não? "Ele é o mais sábio, o mais honesto homem", foi a resposta. "E o povo ficou muito decepcionado por ter dito que ele era doido".

Como tratar a melancolia? Um dos meios é o riso. Os gregos antigos, assevera Burton, tinham uma deusa dos prazeres, e os espartanos, instruídos por Licurgo, sacrificavam em honra do deus Riso, sobretudo após suas guerras e nos tempos de paz. "Risus enim divum atque hominum est aeterna voluptas": porque o riso é o prazer de homens e deuses. Rir é o remédio, mas rir sobremodo em boa companhia. Nas receitas colecionadas por Burton, a hilaridade é um dos recursos mais eficazes contra a loucura e a tristeza.

Após o século XVIII, a cultura ocidental perdeu muito da força curativa proporcionada pelo riso. Se tomarmos os textos de Fichte, Hegel, Schopenhauer, Bergson (passando pelos poetas românticos, como Jean Paul e Baudelaire) o riso é discutido esporadicamente, perdendo o seu 
poder corrosivo, em especial no ataque às superstições, preconceitos, doutrinas filosóficas comprometidas com a dominação cinzenta que se abateu sobre o mundo após Napoleão Bonaparte. A partir do Corso, como demonstrou plasticamente Stendhal em O vermelho e o negro, o tédio e as delações, a censura, os policiais inseridos nas conversas, tornaram a França um país soturno, melancólico. Com ela, a república das letras cobriu-se com a negra teoria, fugindo da verde árvore vital.

Podemos encontrar, nos textos filosóficos posteriores à Revolução Francesa, momentos de risonha crítica. O grave I. Kant, que escreveu algumas sátiras mordentes, como Os sonhos de um visionário explicado pelos sonhos da metafísica, e o Conflito das faculdades, não previu que seus herdeiros estariam apenas de vez em quando bem dispostos e livres da bílis preta. Basta bater os olhos sobre um trecho de Fichte, bem-humorado só na superficie. Seria possível deduzir o mundo e a consciência empírica a partir de um Eu transcendental? O teórico afirma que sim, e suas múltiplas exposições pretendem deixar isto claro como o Sol. Mas os críticos não o entendem. Eles evitam um debate verdadeiro e querem ridicularizá-lo. Ouçamos o próprio Fichte. "Eu digo: 'deduzi a priori a necessidade de admitir ainda outros seres racionais semelhantes a nós'. Eles respondem: 'então, verdadeiramente você deduziu a priori a necessidade de admitir outros seres racionais semelhantes a nós! Reflitamos um pouco sobre isto! Rá-rá-rá! Eu lhes digo: 'deduzi a priori o ar e a luz'. Eles respondem: 'ar e luz a priori; já pensou? Rá-rá-rá! -Rá-rá-rá- Rárá-rá! Riam conosco! Rá-rá-rá! Rá-rá-rá! Ar e luz a priori! Seu saberete! Rá-rá-rá! Ar e luz a priori! Saberete, rá-rá-rá...”. Fulmina o pobre Fichte: "Eu acreditava entrar na república dos sábios. Estou numa república de loucos". Não é de somenos importância que estas explosões trágicas e cômicas ocorram ao redor da passagem do racional ao efetivo, na doutrina científica de Fichte. Este problema é antigo como a filosofia. Já Platão pinta o filósofo, nas representações do vulgo, como um estulto que fala coisas sem sentido.

O caminho do ideal ao empírico, e o retorno em sentido inverso, é a cruz da filosofia e da racionalidade. Entre os poucos textos satíricos escritos por Hegel, o defensor da adequação célebre entre o racional e o efetivo, chamado por isto mesmo de panlogista, estão dois escritos que gargalham contra o vulgo. O primeiro é o famoso "Como o senso comum compreende a filosofia, exposto a partir da obra do Sr. Krug", saído no Jornal Crítico da Filosofia (1802-1803). Krug, sabemos, pediu que o filósofo deduzisse a pena com a qual ele escrevia. Modo de afirmar, muito rapidamente, a separação entre conceito e empirismo. A temática da contingência é básica nisto tudo. Outro texto hegeliano satírico é o também juvenil (mas nem tanto) "Quem pensa abstrato?". Nele, Hegel mostra 
que abstrato é o pensamento preso à subjetividade empírica, à qual todos os misólogos chamam concreta. Em ambos os trabalhos o riso cumpre seu papel crítico e polêmico. Com a idade, Hegel tornou-se cada vez mais "sério". Em seus livros maduros, entretanto, é possível descobrir pontas e ironias bem humoradas, as quais incomodaram (e muito) os seus adversários.

É possível o trânsito entre razão e empirismo? Afastando-se a tentativa idealista de "tudo deduzir segundo um princípio e unificar num sistema todos os elementos da realidade" (Jean-Marie Lardic), podemos dizer que este é o núcleo do pensamento leibniziano e, por ricochete, de Voltaire, no Cândido. Até o século XX, os nexos entre empírico e racional levantam muito palavrório, sobretudo no plano ético. O que é o mal? Esta pergunta esgotou cérebros filosóficos desde Platão e recebeu sucessivas tentativas modernas de resposta, como a Teodicéia de Leibniz. Teilhard Chardin, por exemplo, no século XX, definiu o mal como "um problema estatístico". O que mostra a falta que faz um Voltaire em nosso tempo.

Os vínculos entre conceito racional e intuição empírica foram desenvolvidos por Schopenhauer tendo como suporte o riso. Segundo este filósofo, o saber abstrato reflete a intuição e nela se baseia. Os conceitos não substituem as intuições. Pode haver uma incongruência entre ambos. Assim, afirma Schopenhauer, o racional só pode aproximar-se do intuitivo como o mosaico se aproxima da pintura. O riso é a percepção da incongruência entre conceito e objeto. $O$ pedante, colecionando fórmulas conceituais abstratas sem intuições, torna-se risível $(O$ mundo como vontade $e$ representação, § 13). A causa do risível é sempre a subsunção inesperada de uma coisa num conceito que não the corresponde. $\mathrm{O}$ riso adverte, de repente, a incongruência entre o mencionado conceito e a coisa pensada. $\mathrm{E}$ Schopenhauer cita a anedota do público parisiense que pediu a Marselhesa num teatro, armando um barulho enorme quando não se atendeu este desejo. Um policial uniformizado foi ao palco para dizer que, no teatro, se executava apenas o que estava anunciado no cartaz. "Et vous, monsieur, êtes vous aussi sur l'affiche?", o que provocou a hilaridade generalizada. Assim também o artista Unzelmann, quando era proibido todo improviso no teatro de Berlim. Ao entrar em cena com seu cavalo, este depositou algo inesperado sobre o palco. O público riu muito. Mas aumentou o tom da gargalhada quando Unzelman dirigiu-se ao bicho: "Então, você não sabe que é proibido improvisar?".

O pensamento, segundo Schopenhauer, não abarca todos os infinitos matizes da realidade. $\mathrm{O}$ riso é um estado prazeroso. A percepção da incongruência entre o pensado e o intuído nos causa alegria. Na briga entre razão e intuição a segunda vence sempre porque não está sujeita a 
erro. O contrário do riso é a seriedade. O homem sério se convence de que pensa as coisas tal como elas são e que elas são como ele as pensa. Por isto, escorrega muito fácil no ridículo. As pessoas medíocres, assevera o filósofo, moral e intelectualmente falando, têm um riso forçado e falso. Poderíamos dizer, arremata, que a maneira pela qual uma pessoa ri e as coisas que a fazem rir são indícios seguros de seu caráter. O mundo moderno, adverte Schopenhauer, caiu deploravelmente na ternura pelas palavras. O eufemismo tomou conta de tudo. Se o filósofo estivesse entre nós, ele certamente teria desgosto de nossa linguagem hipócrita e politicamente correta. "Linguagem pomposa", assim terminam suas considerações sobre o riso, "pensamentos vulgares; esta é a característica dos tempos vulgares e por isto hoje chamamos de 'humorista' ao que antes se chamava 'bufão"'. (Capítulo 8 de $O$ mundo como vontade e representação, segunda parte). Na mídia televisiva, no Brasil, temos inúmeros exemplos desta efetividade.

A partir dessa marca dos indivíduos segundo o seu riso, Nietzsche retira um modo de classificar os filósofos. "Permito-me", diz ele, "estabelecer uma hierarquia dos filósofos segundo a qualidade de seu riso, colocando no ápice os capazes de um riso dourado. Admitindo que os próprios deuses cultivem a filosofia, o que várias conclusões levam-me a crer, não duvido, também, que eles, filosofando, saibam rir de um modo novo e super-humano, às custas de todas as coisas sérias. Os deuses são brincalhões; parece que, mesmo durante a celebração dos ritos sagrados, não podem segurar o riso". "Rirá melhor quem rir por último". Com este dito popular Diderot termina $O$ sobrinho de Rameau, uma das obras-primas filosóficas e literárias da cultura ocidental. Como poderíamos classificar o pensamento de Voltaire, segundo este critério? Nosso homem foi recebido como um furacão vingador pelos seríssimos padres, políticos, pedantes em geral, que infestavam a sociedade do Antigo Regime.

Após o Termidor, um espírito sério dominou os discursos filosóficos. O jargão das profundezas passou a ser norma, banindo o enunciado claro e distinto. A linguagem sibilina tornou-se patente, anunciando rigor aos incautos. A charlatanice romântica, presente numa fala pítica, levantou objeções até mesmo de Hegel, normalmente visto como ligado ao discurso esotérico. Contra os românticos e seu pretenso mergulho nas profundezas naturais e anímicas, algo impossível ao universo comum dos seres pensantes, mas destinado a ser compreendido apenas pelos geniais poetas e pensadores dos pequenos círculos iniciáticos, Hegel desfechou duros ataques ao longo de seus escritos. "Assim como existe uma extensão vazia", diz ele no "prefácio" à Fenomenologia do espírito, "existe também uma profundidade vazia". O visado, aqui, entre outros, é Jacobi, cuja representação do sujeito põe este último como "profundo" e 
não disposto a se perder, comunicando-se, no exterior. $\mathrm{O}$ ego, nas palavras de Hegel, é tão sensível, tão auto-centrado, tão dolorido e cheio de não-me-toques, que o melhor é chamá-lo "o absoluto em negligé" (Estética).

A mania da profundidade chegou aos nossos tempos. Quanto mais jargonística é a fala de um teórico, mais ela tende a ser confundida com rigor. Não apenas Carnap, K. Popper e outros eminentes críticos, por exemplo, apontaram o charlatanismo da profundeza em Heidegger, para indicar apenas um destes oráculos. Sacral sem figura santa. Deste modo, indicando que o discurso filosófico laico mantém a pretensão de possuir uma aura só captável pelos iniciados, T. Adorno caracteriza o profetismo heideggeriano, em O jargão da autenticidade. As orações dos inspirados heideggerianos fogem da prova lógica e histórica. Aprendendo com seu oráculo maior um meio grosseiro de eludir o conceito, por meio de pretensas etimologias produzidas ad hoc, os seguidores desta seita místicofilosófica mergulham fundo no palavrório. E somos obrigados a ler ou a ouvir termos da gíria esotérica, com insistentes hífens que dão aos tolos o gosto ilusório da profundidade. As palavras cheias de hífens e tautologias (a questão da questão, a pergunta da pergunta etc.) no discurso dos que imitam Heidegger usurpam o lugar da filosofia e adubam o terreno para falas compromissadas com o atraso tecnológico. Como bons irracionalistas modernos, os heideggerianos recebem emolumentos, gastam-nos em computadores e livros, mas batem sempre na tecla: a técnica corporifica a metafísica.... O lero-lero anticientífico e contrário à técnica não os impede de gozar os avanços do engenho humano. Mas seu palavrório não questiona a falta de acesso das multidões negativamente privilegiadas ao saber, à tecnologia de ponta. Enquanto isto, tais misólogos gastam verbas acadêmicas - que deveriam ser dirigidas para os laboratórios onde se cura, onde se produz máquinas e conhecimentos úteis à população - produzindo verborréia ou, na saborosa fala francesa, "mauvaise métaphysi$q u e^{\prime}$.

Jacyntho Lins Brandão (1990), em artigo excelente sobre "Doentes, doença, médicos e medicina em Luciano de Samósata" lembra a cura de um pedante que tornava arcaico ao máximo seu discurso, sem nenhuma idéia atrás do palavrório impressionante e oracular. O culto das palavras raras, o tom distante e profundo de uma fala semelhante, tornou Lexifanes, o mencionado pedante, um paciente que deveria sofrer um vomitório, para livrar-se do blablablá ininteligível a que estava submetido. O termo, utilizado por Luciano para definir a verborréia arcaizante de Lexifanes, cabe às mil maravilhas para nossos heideggerianos: lero. Isto nos conduz ao De garrulitate, onde Plutarco caracteriza esta doença própria ao boquiroto. Este fala e não ouve, encantado que está com sua pró- 
pria voz e profunda sabedoria. Outro caso de pedantismo explícito, muito próximo ao discurso heideggeriano, é o de Panurgo, no início do nono capítulo do Pantagruel. De fato, é ridículo constatar como os charlatães irracionalistas semeiam sua fala com etimologias gregas, alemãs, latinas etc, para espanto dos beócios. Após ter Panurgo esgotado os "enfeites" discursivos com o alemão, italiano, inglês etc. Pantagruel, atônito, lhe pergunta: "Parlez-vous christian?". Depois do grego, nova pergunta: "ne sçavez-vous parler françoys?". E Panurgo responde em bom francês, porque era originário da França. É verdade que a fome obrigou o pedante a parar com seu palavrório. A fome não é problema dos pedantes atuais. Só nos resta, com o positivismo lógico, um excelente remédio, odiado pelos heideggerianos, lhes perguntar: "parlez-vous christian?".

Essa famosa linguagem cifrada da Eigentlichkeit possui origens no romantismo irracionalista do século XIX, hoje retornando às teses e trabalhos filosóficos, com muita força, no mesmo instante em que os neo nazismos e as intolerâncias retornam à Europa e ao mundo. As críticas dirigidas por Hegel contra Schleiermacher são eloqüentes, neste sentido. Trata-se, para este último, de, na filosofia, atingir a concepção própria de mundo. Ora, retruca Hegel, "na subjetividade, na intuição própria do mundo encontra o Eu a sua maior tolice".

Os românticos não têm conceito (até aí, um xingamento comum em Hegel, para quem Newton não sabia que pensava conceitualmente, como o senhor Jourdan não sabia que conversava em prosa). Eles escrevem, todos, como inspirados que falam por meio do monólogo "e só entendem-se mutuamente por encontrões e apertos de mãos, por sentimentos mudos. E o que dizem é trivialidade" (História da filosofia). Quando lemos as análises da linguagem heideggeriana, por Carnap, saímos com a mesma impressão: o tom oracular e complicado esconde, não raro, trivialidades e atitudes misólogas, enunciadas com uma seriedade assustadora.

Essa forma de escrever, bárbara e indecorosa, mostrou-se eficaz sobretudo no combate ao pensamento dos séculos XVII e XVIII. Contra a antiga enárgeia, a escrita luminosa e distinta, o romantismo erigiu um palavrório esotérico que foge, justamente, da verificação universal pela comunidade dos pensantes. Nesta logomaquia conservadora contra as Luzes, a vítima por excelência foi Voltaire. Não partilhando a seriedade dos filistinos românticos, para quem esta atitude se restringia ao subjetivo, aos batimentos cardíacos que os comoviam até às lágrimas auto-indulgentes, às geniais intuições que só eles podiam obter, Voltaire foi enxergado como não-sério. Não exercendo a profundidade romântica, manifesta pela Naturphilosophie à cata do originário, do primitivo, do inconsciente, Voltaire foi banido para a pátria gaiata e incômoda da su- 
perficialidade. Com ele, o século XVIII inteiro foi acusado de ingenuamente acreditar no progresso, na técnica, na razão. O libelo, por sua vez, é tudo, menos ingênuo.

Quem ri não é sério. Esta equação é moderna, romântica, conservadora, irracionalista. Mesmo Platão, conforme escreve Pascal, não seria um homem sério nesta perspectiva. Quando ele escreveu as Leis, assevera Pascal, o grego brincava. "Esta é a parte menos filosófica de sua vida". Aqui entramos num desvio que não podemos seguir hoje. Trata-se da fala, do pensamento, da escrita. Todos conhecem as reservas platônicas à escrita. E Platão talvez seja o escritor mais soberbo que algum dia lemos. $\mathrm{Na}$ Carta VII, está dito com todas as letras: "não existe nenhum escrito que seja meu, e isto jamais existirá". Acostumados às montanhas de comentários sobre as "doutrinas platônicas", esta afirmação nos espanta. O saber que eu possuo, arremata Platão, não se pode formular em proposições. Ele resulta de um comércio repetido com a própria matéria desse saber. Depois de muito freqüentar um problema, "súbito, surge uma luz que se espalha na inteligência, este saber produz-se na alma e, doravante, é nutrido por ele mesmo".

Por este motivo, termina Platão, "nenhum homem sério, ocupado com questões sérias, arriscar-se-á a deixá-las cair no falatório público, escrevendo-as, e as expondo aos maltratos e às dúvidas. Por isto, quando se vê algo escrito por alguém sério, seja uma lei por um legislador, seja este ou aquele assunto, deve-se investigar o caráter deste escrito e perceber que não se trata do que é o mais sério. Supondo que ele acredite que estas coisas escritas são realmente sérias, e por tal motivo ele as depositou em escritos, então é certo que os deuses, não os mortais, the arruinaram a cabeça" (344, c-d).

É justo essa desconfiança na seriedade que possibilitou o combate ao pedantismo na pena de Erasmo, de Rabelais, de Voltaire e de Diderot. Mas o pedantismo, especialmente o misólogo e o instalado nas cátedras, tem mais folego do que o espírito. Ele se enamora da letra, cultuando formas embalsamadas e repetindo fórmulas. O pedantismo é sério. Por isto, sentiu os golpes das Luzes e retrucou instalado na pequena subjetividade.

O leitor deve estranhar essa longa introdução sobre o riso, a seriedade, o cômico. Mas fiz questão de nos deter em todas essas aléias, devido ao preconceito mais arraigado contra as Luzes e, particularmente, contra Voltaire: o de que ele não seria propriamente filósofo, mas apenas um literato engraçado que infernizou a vida dos padres e dos preconceituosos de seu tempo. A tarefa filosófica de Voltaire - e de todos os franceses ligados de um modo ou outro à Enciclopédia diderotiana - seria menor: traduzir o empirismo inglês em letras elegantes, buscar os padres em baixo de todas as camas e demais recantos escondidos nos lares de- 
centes, gritar contra a massa ignara que adorava um auto-de-fé. Este, para usar o jargão de Hegel e de seus amigos românticos, é o lado interessante das Luzes, o seu lado negativo. Já no que tange ao positivo, o valor filosófico dos iluministas seria quase nulo. Ou seja: os pensadores a que nos referimos seriam apenas e tão-somente propagandistas, ideólogos para bem dizer a coisa. As Luzes inteiras, fora o negativo, resumir-se-iam a um palavrório imenso, ainda conforme nosso bom Hegel, tão imbuído de seriedade.

Não por acaso invoquei o riso pascalino para entrar em nosso tema. Pascal também é tido, por muita gente boa, como apologeta, santinho, beato, geômetra etc. Tudo, menos filósofo. Descartes, este sim, merece entrar no cenáculo especulativo. Nenhum cartesiano aceita, até hoje, as pontas contra seu ídolo nas Pensées. "Descartes, inútil e incerto...". Esta alfinetada abala os que decoraram as regras para a condução do espírito e rezam pela cartilha das Meditações. Mas ela faz pensar. E não é esta, justamente, a essência da filosofia? É praticamente impossível falarmos em Pascal sem mencionar Voltaire. Jean Deprun, num fino trabalho sobre a inquietação no século XVIII francês, indica algo importante neste sentido: a própria idéia de inquiétude pascalina, estratégica para entender a descrição do homem no universo e na sociedade, encontra-se desenvolvida ao longo do Cândido, como tédio. Há uma espécie de reverberação entre o riso de Pascal e o de Voltaire.

Vejamos alguns juízos de Voltaire sobre Pascal. O piedoso, na opinião voltaireana, era bastante afastado do rigor acadêmico. Ele riu-se muito de autores e de livros sobre os quais nunca bateu os olhos, pelo menos por inteiro. É isto o que diz Voltaire na "Traduction d'une lettre de Milord Bolingbroke": "Pascal era muito eloqüente, era sobretudo um folgazão. Parece que ele tornar-se-ia bom geômetra: o que não concorda muito com a zombaria e o cômico que reinam em suas Cartas provinciais; mas sua periclitante saúde tornou-o logo incapaz de estudo continuado. Ele era extremamente ignorante sobre a história dos primeiros séculos da Igreja, bem como ignorava quase toda outra história. Alguns jansenistas me confessaram, quando estive em Paris, que ele nunca leu o Antigo Testamento inteiro; e acredito que, de fato, poucos homens fizeram tal leitura, exceto os que têm a mania de comentá-lo. Pascal não leu nenhum dos livros dos jesuítas dos quais ele zomba em suas cartas. Eram ajudantes de Port-Royal que lhe forneciam as passagens que ele transformava tão bem em ridículo".

No Século de Luís XIV, capítulo 37, "Do jansenism", Voltaire afirma que Pascal fez mais do que os partidários de Port-Royal em busca de tornar odiosos os jesuítas: ele os tornou ridículos. "Suas Cartas provinciais, que apareceram então, eram um modelo de eloqüência e de zomba- 
ria. As melhores comédias de Molière não têm mais sal do que as primeiras Cartas provinciais: Bossuet não possui mais sublime do que as últimas". É verdade, finaliza Voltaire, "que o livro inteiro elevou-se sobre um fundamento falso. Nele, se atribuía aos jesuítas todas as opiniões extravagantes de vários jesuítas espanhóis e flamengos". Mas, em qualquer hipótese, as Provinciais, na opinião de Voltaire, são "o livro melhor escrito que já aparecera na França". Os padres de Santo Inácio conseguiram ordem do Parlamento de Provence para incinerar as ditas folhas, "eles não se tornaram menos ridículos, mas tornaram-se mais odiosos". Nas Variantes do templo do gosto, Voltaire diz que as "Cartas provinciais são a mais engenhosa, a mais cruel e, em certos lugares, a mais injusta sátira que jamais foi realizada".

Injustas, sim, mas profundas. E aqui encontramos, na pena do $s u$ perficial Voltaire, o elogio da profundidade em filosofia, para espanto dos que nele apenas enxergam películas de pensamento. "De mil leitores", afirma Voltaire, "não há talvez um que não prefira em segredo o espírito de Fontenelle ao sublime de De Meaux, e a imaginação das Cartas persas à perfeição das Cartas provinciais, onde nós nos espantamos ao ver o que a arte possui de mais profundo, com toda a veemência e ingenuidade natural. É que as coisas só impressionam os homens segundo a proporção que elas têm com o seu gênio. Assim o verdadeiro, o falso, o sublime, o baixo etc., tudo desliza sobre muitos espíritos e não os atinge: é pela mesma razão que as coisas muito pequenas escapam à nossa vista $\mathrm{e}$ que as grandes a ofuscam. Donde vem que tanta gente ainda prefere à profundeza metódica de Locke a memória fecunda e descosida de Bayle".

Há uma sátira superficial recusada por Voltaire. Ela volta-se contra os sujeitos, não se dirigindo ao universalmente ético. Esta variante da sátira "gera inimizades eternas ... As famílias, os amigos, entram nas querelas; é o veneno da literatura. Combati ousadamente nesta arena, e jamais fui o agressor" (Carta a M. de Pezay, 9/3/1767). A sátira grosseira faz rir, mas nós a desprezamos. Ela é particularmente odiosa, na crítica "mercenária de ignorantes que insultam contra pagamento as artes que eles nunca praticaram, que denigrem os quadros do salão sem saber desenhar, que se elevam contra a música de Rameau sem saber solfejar: miseráveis zangões que vão de colméia em colméia para serem expulsos pelas abelhas operosas!" ("preface", Les Scythes). Neste sentido, diz ainda Voltaire, "...tanto as letras são queridas por mim, quanto o nome de satírico é um título que eu desprezo e detesto" (Discours de M. Voltaire en réponse aux invectives de ses détracteurs). A sátira vulgar atende ao desejo do povo, sempre em busca de distração que detenha um pouco sua inquietude. Nota-se, em Voltaire, na crítica dessa via filistina da sátira, uma continui- 
dade da descrição pascalina sobre o divertissement, fruto da angústia dos medíocres com sua própria existência. Basta ler a Carta 61, dirigida à Marquesa du Chatelet, cujo subtítulo é justamente "sobre a calúnia":

\footnotetext{
Jerusalem a connu la satire./Persans, Chinois, baptisés, circoncis, Prennent ses lois : la terre est son empire;/Mais, croyez-moi, son trône est à Paris.Là, tous les soirs, la troupe vagabonde/ D'un peuple oisif, appelé le beau monde,/Va promener de réduit en réduit/L'inquietude et l'ennui qui la suit.
}

O próprio Voltaire diz ter lutado na arena satírica, sem nunca atacar ninguém pessoalmente. Licença poética, ou simples tática no despiste polêmico, o fato é que ele escreveu Le Mondain, Le pauvre diable, La vanité, Le Russe à Paris, Les chevaux et les ânes aux sots, Le Marseillais et le lion, Les trois empereurs en Sorbonne, Les cabales, La tactique, Le dialogue de Pégase et du vieillard, e muitas outras sátiras, algumas eminentes, outras lançadas contra pessoas definidas. O pobre Rousseau caiu no conto do Voltaire sincero, atribuindo uma sátira a ele dirigida pelo autor do Cândido a outra pessoa. Mas estas são outras histórias. Se Pascal escreveu as mentirosas, Voltaire não deixou de usar o mesmo recurso para espalhar o pavor entre os adeptos da infame. $\mathrm{O}$ fato de cair no gênero baixo da sátira não impede o desejo e a prática do que é elevado naquele estilo, sobretudo tendo como modelo a leveza de Luciano de Samosata.

Qual a via correta na sátira? Qual o alvo eminente neste gênero? Os grosseiros libelistas não realizam nada que seja digno das letras. $\mathrm{Na}$ "Correspondência", lemos a carta datada de 5 de junho (1751). Nela, Voltaire anuncia o envio, a Frederico II, de sua sátira intitulada "Diálogo entre Marco-Aurélio e um Recoleto". E o que diz nosso escritor sobre esta peça? "Tentei escrevê-la segundo a maneira de Luciano. Este Luciano é ingênuo, ele obriga os seus leitores a pensar, e somos sempre tentados a ampliar seus Diálogos. Ele não quer ser espirituoso. O defeito de Fontenelle é sempre querer mostrar graça: sempre vemos a ele, e nunca o seu herói; ele os faz dizer o contrário do que deveriam; ele sustenta o pró e o contra; ele só deseja brilhar. É verdade que, no fím, ele consegue isto; mas ele fatiga depois de algum tempo, porque sentimos que nada é verdadeiro em tudo o que nos apresenta. Percebemos o charlatanismo, e ele repugna”. O satírico superficial expõe a si mesmo, mostra a sua própria graça. O profundo, como Luciano, expõe todas as faces do objeto satirizado. O primeiro nos cansa - como, digamos, cansa ler as intermináveis lamentações dos românticos sobre o seu ego dolorido - com sua saliência importuna. O segundo, abre-nos o caminho do herói e da humanidade, com variegada experiência da alteridade.

Precisamos nos deter um pouco na marca atribuída por Voltaire a Luciano. O termo naif faz pensar. Para Diderot, naif, além da simplicida- 
de, acumula os significados de inocência, verdade, originalidade. Oposto ao naif temos a manière. Esta significa, para muitos autores do século XVIII, o que a hipocrisia representa nos costumes. Oposto a ingênuo, temos o que é afetado, lisonjeiro, que deseja agradar o observador. Quando, contrastando Fontenelle e Luciano, Voltaire afirma que o último é ingênuo, ele resume um modelo moral, artístico, civilizatório. Numa sociedade qualquer, sobretudo na república das letras, quem cultiva e exibe seu ego e deixa o assunto para segundo plano, no juízo severo de Voltaire, é charlatão. E superficial. O que ocorre na sátira também surge na filosofia. Vimos acima Voltaire elogiando a profundidade metódica de Locke, contra a saliência e virtuosismo de memória exibidos por Pierre Bayle.

De Maistre, nas Soirées de Saint-petersbourg indica o quanto o trabalho dos enciclopedistas, traduzindo o século XVI de Francis Bacon e o pensamento de Locke para a cultura francesa, fizeram um trabalho importante, teórica e politicamente. Só este labor de importação, com seu mérito - no caso de De Maistre, crime - dos philosophes e de Voltaire, exigiria muita cautela das pessoas sensatas. Para De Maistre, Locke é o escritor que rompe a separação das substâncias - espiritual e material abalando o fundamento da crença na imortalidade, injetando de vez a dúvida na doutrina cristã do Bem e do Mal. Os estragos metafísicos começam, como sempre na genealogia de Joseph De Maistre, na Reforma, a qual se aperfeiçoa em pecado e malícia na escrita de Locke, Hume, e de outros com o mesmo defeito.

Locke, como todos os filhos de Lutero, só pode dizer a palavra não contra a autoridade religiosa, política, científica. A origem comum dos pensamentos e das mais sublimes verdades ortodoxas, em Locke, deixam De Maistre apoplético: tal origem comum arranca a raiz transcendente da fé, afastando-a da razão. Daí, para a fama de pura negatividade, jogada por De Maistre sobre Locke e as Luzes - fama assumida sem maiores cautelas por Hegel e pelos românticos - nada mais faltou. É superficial quem rompe com a base da fé positiva e autoritária, desejosa de ornar-se com o manto da razão. Os irracionalistas do século XIX, e os de hoje, não se cansam de repetir esta cantiga, forjada por De Maistre, inimigo jurado dos direitos humanos e da liberdade.

O que De Maistre não perdoa mesmo é o símile proposto por Voltaire entre Locke e Pascal. O primeiro seria o Pascal da Inglaterra. Vejamos o que diz De Maistre: "não sou ternamente cego para com François Arouet: eu o suporia muito leviano, muito mal-intencionado (...) mas não acreditaria, nunca, que um homem de tanto bom gosto e tato se permitisse uma comparação extravagante deste naipe, se ele tivesse julgado por si mesmo". E De Maistre invectiva Locke, o "tedioso", cuja filosofia é a de 
um almanaque, louvando Pascal, "apologista sublime, polêmico superior, capaz de tornar divertida a calúnia". Pascal, segundo De Maistre, é sobretudo profundo.

Atentemos muito bem: o laico John Locke é superficial e tedioso (lemos estes epítetos, contra as Luzes, na pena de Hegel). O cristão Pascal é profundo e engraçado, mesmo caluniando. Porque Voltaire, leviano mas "homem de bom gosto", cometeria a bobagem de comparar os dois heróis do pensamento? A resposta de Joseph De Maistre é um primor de má-fé e de suposição caluniosa: porque Voltaire não leu o inglês inteiramente. A leveza voltaireana, sujeita às ocupações várias, como o muito escrever, muito gozar dos prazeres de mesa e cama, o teria impedido de passar os olhos atentos sobre o princípio, o meio, o fim dos textos excretados por Locke.

Se Voltaire tivesse lido o empirista, sentencia De Maistre, teria notado que no Entendimento humano estava, in nuce, a Revolução Francesa. A escrita de De Maistre é mais saborosa: "após ter posto os fundamentos de uma filosofia tão falsa quanto perigosa, o fatal espírito de Locke dirigiu-se para a política, com um sucesso não menos deplorável. Ele falou sobre a origem das leis tão mal quanto parolou sobre a origem das idéias; e ainda sobre este ponto ele colocou os princípios dos quais vemos as conseqüências. Estes germes terríveis teriam abortado, talvez, silenciosamente, sob o gelo de seu estilo; recebendo vida na lama de Paris, eles produziram o monstro revolucionário que devorou a Europa".

Um pensamento superficial que não aceita o juízo da autoridade na religião, na política, na arte, na ciência, só pode conduzir, afirma nosso reacionário, à catástrofe democrática. Este diagnóstico impera nos espíritos conservadores que buscam no cristianismo político, de Joseph de Maistre até Augusto Comte, deste até o movimento L'Action Française e desta à TFP, o princípio da ordem e da obediência, a dominação que abole a crítica e a liberdade. Todos os herdeiros desse conservadorismo no século XX caluniaram as Luzes, dizendo que seus postulados de igualdade e liberdade são metafísicos. Maurras, Mussolini, Hitler, só quiseram, como De Maistre, instrumentalizar o catolicismo enquanto domador das massas. Eles, também como o maçon De Maistre, nunca acreditaram nos dogmas e na ética dos evangelhos. É natural que os livros dos enciclopedistas e de Voltaire tenham ardido nas fogueiras destes rebentos da contra-revolução. Importa notar a técnica de refutação assumida por De Maistre: trata-se do velho recurso de atacar as subjetividades, deixando de lado a passagem pelo próprio assunto, a coisa. Dizer que Voltaire era vaidoso, que ele escrevia muito, que ele não deixava a mesa e a cama, são, na escrita de Joseph De Maistre, prova de que ele não leu os ingleses 
por inteiro. Esta técnica sofística vai contra todas as determinações filosóficas do decoro, o qual exige que se trate a coisa na sua própria medi$d a$, não a reduzindo a fatores subjetivos e contingentes.

Tamanho decoro é partilhado por todos os defensores da razão moderna, a começar pelo pai da ciência experimental, Francis Bacon, atingindo I. Kant, na voga das Luzes. Tome-se a Razão pura: já na epígrafe daquele monumento temos a citação baconiana: "De nobis ipsis silemus: De re autem, quae agitur, petimus...". Calamos sobre nós mesmos, falamos das coisas. Esta é a regra desobedecida por Fontenele, segundo Voltaire, esta é a norma que encontramos em Luciano. Hoje, no final do século XX, após as inúmeras tentativas de afastar o sujeito enquanto centro do mundo, do saber, da ética e das artes, as palavras desta razão ampla, decorosa, trazem alento ao pensar. Num mundo do Starsystem, no qual o mercado define as celebridades teóricas, e onde as doutrinas são vendidas segundo engenhosas operações de marketing, e onde egoidades inchadas brilham durante momentos para depois se precipitarem no silêncio do lixo cultural, vale a lição de ética na escrita, reproduzida por Voltaire.

O bom-humor e o diálogo filosófico sempre tiveram um convívio difícil. A sua incongruência foi sublinhada por Luciano. Segundo ele, o saber dogmático e o riso são eternos inimigos. O diálogo teórico é serio em demasia, "fillosofando sobre a natureza e a virtude". A comédia zomba "dos que pensam coisas elevadas. Ela só tem um prazer: rir-se deles, empurrando-os para as liberdades dionisíacas" (Prometeu em palavras). Ninguém melhor do que Luciano mostrou o ridículo do fanatismo. Poucos exibiram, como ele, as tolices dos seríssimos filósofos. Luciano foi seguido por Seneca, Rabelais, Erasmo, Morus, Voltaire, Diderot, James Joyce, G. Grass. Nenhum pedante especulativo venceu esta via láctea risonha. A filosofia posterior a Hegel deseja ser coisa séria. Ela não admite o riso no santuário do Conceito. Salvando o diálogo, Hegel não soube o que fazer com sua irmã inimiga, a sátira.

Onde, na evolução do espírito, colocar o gênero satírico? Ele não pertence, dogmatiza Hegel, à épica ou à lírica. "Não se produz, em seu âmbito, poesia verdadeira ou verdadeira obra de arte". Luciano, segundo Hegel, volta-se "com leveza contra tudo: heróis, filósofos e deuses ... Mas se alonga e se perde no palavrório ... tornando-se particularmente enfadonho". Estratégia hegeliana: quando enfrenta um texto indigesto à razão dialética, nosso pensador decreta que ele não tem graça. Luciano "é tedioso" (Lições sobre a estética). A metafísica francesa das Luzes não passa de "uma enxurrada de falatório tedioso" que nada conceitualiza (História da filosofia). Luciano escreveu um diálogo hilariante sobre cer- 
ta feira onde as mercadorias seriam... os filósofos das mais variadas tendências. É possível imaginar onde ele colocaria o grave Hegel.

A linguagem cristalina, notável em Luciano, impressionou as Luzes. Mas já Focion via nele um excelente "estilo, servindo-se de vocabulário claro, próprio e que se distingue pela eficácia ... Sua composição foi por ele realizada de tal modo harmonioso que o leitor não sente estar lendo prosa, mas uma doce melodia sem música, a qual se instila nos ouvidos" (Cf. Mattioli, 1980). Entre Focion e Hegel, quem possui bom gosto não tem escolha. Hegel considera Luciano e a sátira menipéia tediosos. Seu juízo é o mesmo para as Luzes. Vejamos o nexo entre o elemento satírico e Voltaire. Este último chegou a ser conhecido como "um Luciano elevado à suprema potência da curiosidade, do saber, da ironia e da eloqüência" (Émile Egger). Razão e sátira constituem um só bloco. Voltaire e Luciano mostram, nos seus textos, o trabalho dissolutor das crenças carcomidas, devastando o irracionalismo que domina os cérebros do vulgo e dos filósofos dogmáticos.

Ao tecer considerações sobre Swift, outro discípulo de Luciano, Basil Willey aponta um traço crucial das técnicas satíricas. Nelas, o alvo maior é nos forçar a ver "coisas reais e familiares como se fosse a primeira vez, como se nós fossemos visitantes de um outro planeta ... ou de algum quartel da Razão". O escritor retira o objeto satirizado "da seqüência familiar que normalmente o reconcilia conosco, e nos faz vê-lo como ele é em si mesmo, como, no conto de Andersen, a criança viu o imperador nu". O inesperado no habitual: dominando esta técnica, o humorista filosófico desmistifica a ordem existente, solapa as bases do autoritarismo. A razão satírica impera no discurso das Luzes. O pensamento conservador combateu a crítica, impediu que os homens olhassem com estranheza os absurdos do mundo. Segundo Burke, o pai do conservadorismo, "a política não deve se adaptar à racionalidade humana, mas à natureza humana, da qual a razão é apenas uma parte".

A sátira lucianesca, no polo contrário ao de Burke, ajuda-nos a ver o que julgamos natural com novos olhos, os da razão sem peias e hostil aos dogmas. Nela, os personagens encarregados de nos fazer enxergar de modo diferente são apresentados por meio de três modos: por katabasis, indivíduos vivos se dirigem para o mundo inferior (como o herói Menipo, que desce ao Hades). Por anabasis, os personagens críticos elevamse ao mundo superior e de lá observam os costumes ridículos dos humanos (Menipo sobre a Lua, onde vê os homens como formigas atarefadas e tolas). A terceira técnica é apresentar os próprios mortos conversando sobre os absurdos observados no mundo, como ocorre no "Diálogo dos mortos". Esta maneira de distanciar-nos do que vivemos, possibilitan- 
do-nos encarar os fatos por outros ângulos, recebeu, na fala de Bertolt Brecht, o nome definido: Verfremdung.

Em Voltaire, esses artifícios do estranhamento encontram-se em textos como a "Conversa de Luciano, Erasmo e Rabelais nos Campos Elíseos" (1765). Ali, o sarcástico Luciano exclama, após a narrativa de muitas tolices do catolicismo político: "Vocês ganham de nós em loucura! As fábulas de Júpiter, de Netuno e de Plutão, das quais nós rimos, eram respeitáveis se comparadas às tolices que enfatuam o seu mundo". Um outro exemplo de anabásis enquanto técnica lucianesca, seguida por Voltaire é a sátira Os três imperadores na Sorbonne (1768). No início, surge o tema pascalino da inquietude. Os imperadores estão bem no seu repouso, mas "seu espírito está inquieto, e se cansa de tudo, com freqüência um beato se entedia no paraíso". Após várias peripécias pelo mundo sábio, o trio chega à Sorbonne, onde descobre que, sendo pagão, está danado. Marco Aurélio diz a um doutor pedante - o que é sinônimo - "vocês não conhecem as pessoas de quem falam, as Faculdades às vezes são mal instruídas sobre os segredos do Altíssimo, embora eles sejam revelados. Deus não é tão ruim nem tão tolo como vocês afirmam". O doutor, Ribaudier no caso, cai em convulsões dignas dos energúmenos de São Medard, e chama o imperador de deísta, ateu, ímpio, herético, inimigo do trono e do altar, e intenta um processo contra ele. O fim da sátira diz que os três imperadores pensavam estar na Sorbonne, mas se enganaram, tinham visitado um hospício de loucos. Erro de lugar, erro de pessoas, erro teológico: tudo isto mostra a intolerância fanática que transforma a universidade, lugar da ciência, em foco de ódio eterno, sob o reino e a censura da Faculdade de Teologia.

No Diálogo entre Marco Aurélio e um recoleto, logo nas primeiras frases do monge ao imperador, que também veio de outro mundo para saber o que se passava nos tempos novos, temos o epíteto preferido pelos intolerantes. O estóico seria um danado. Ao saber que agora, em Roma, domina um Papa, que nela reina a inquisição, e que o império romano está circunscrito à uma cidade sem importância, Viena, o sábio latino exclama: "Você me conta estranhas coisas. Todas estas grandes mudanças não se fizeram sem grandes infelicidades. Eu amo sempre o gênero humano, e o lamento". No final, o recoleto excomunga o imperador e segue para as matinas. "E eu", diz Marco Aurélio, "vou me unir ao Ser dos seres".

Estóicos ou não, o importante é que os imperadores romanos surgem, nos diálogos de Voltaire, feitos ao modo de Luciano, como ícones da tolerância. Neste sentido, eles trazem a dupla implicação proporcionada pelo encontro, nos textos de Luciano, de um ceticismo atenuado e da atitude cínica. Não é possível tolerar o pensamento e os costumes alheios 
se o sujeito acredita residir na verdade absoluta. É justo este o tema dos textos satíricos voltaireanos. E este é também o núcleo dos diálogos lucianescos. A sátira, na linha de Luciano, é séria e cômica ao mesmo tempo. Se o pensamento é apenas sério, ele facilmente cai na armadilha dogmática, degenerando em fanatismo. Se for apenas engraçado, não atinge a polifacetada experiência humana. Como a razão, a sátira abarca os vários ângulos do real, sem prender-se com exclusividade a um deles.

Vimos, acima, Platão ironizar o político que pretende escrever coisas sérias. O grande herói de Luciano, o cínico Menipo, reúne a fama de ser ao mesmo tempo um risonho zombeteiro e ácido acusador, muito sério, dos desregramentos humanos. Na Dupla acusação, Luciano diz que Menipo "é o que late mais forte, sendo o mais mordente de todos os antigos cínicos". Suas mordidas são tanto mais profundas quanto ele as produz rindo e sem que nos apercebamos delas. Marco Aurélio, nos Pensamentos, o apresenta como ranzinza crítico do gênero humano (VI, 47). Como afirma um editor nosso contemporâneo, Léonce Paquet, há muitas razões para acreditar que Menipo está na origem do gênero literário chamado spoudaio-géloion (sério-cômico), central em Luciano, Varrão, e na seqüência filosófico-literária que vai de Erasmo até Voltaire. Acostumados ao divórcio entre riso e conceito, após Hegel, parece-nos estranho que, para falar sério, é possível sorrir, ou mesmo, escarnecer, de nós mesmos e da tolice humana que reside em nós e em nossos próximos.

Luciano inova, literária e filosoficamente, diante de Platão e de Aristóteles, nesse campo do riso e do sério. No Filebo platônico, lemos que o principal efeito da comédia, o riso, liga-se indissoluvelmente ao prazer maligno sentido diante da exposição do outro à ignorância de si mesmo. A característica principal do caráter cômico é um vício da ignorância impotente. Porque a comédia provoca um prazer misturado com a dor, Platão a condena como indesejável. Luciano, em plano oposto, une o riso e a seriedade para atingir dois alvos: desmacarar o dogmatismo tolo dos filósofos e ensinar um comportamento moderado, em todos os sentidos.

O lado satírico dos textos é um meio utilizado para desarmar o tolo ou o dogmático. Este ri da tolice apresentada, não suspeitando que ela é apenas um espelho de sua própria sandice. Dentro, escondido, está o ensinamento sábio. Erasmo, no Adágio Silene de Alcibíades, usou ao máximo todos os símiles deste exterior ridículo com a sublime sabedoria interna. Rabelais compara seu Gargantua e seu Pantagruel ao osso cuja gordura alimentícia está escondida. Quem ler um escrito assim, sem conhecimento prévio, o toma como pura brincadeira. Mas os temas mais árduos da metafísica, da ética, das artes, jazem nas suas linhas de corte duplo. O diálogo de Luciano chamado Dionísios é apresentado por ele 
mesmo como exemplo do estilo sério-cômico de pensar e escrever. Dionísios, o deus criança, entra em guerra contra os indianos. Seu exército é risível: um velho pançudo, Sileno, com pés de bode e chifres, mulheres descabeladas, as bacantes, sátiros. Quando enxergam este incrível exército, os indianos caem na gargalhada. Ele não representava nenhum perigo sério. Mas assim que a batalha começou, o barulho infernal dos sátiros, a violência das bacantes, a força dionisíaca fizeram dos indianos prisioneiros e vencidos. "Muitas pessoas estão na mesma condição dos indianos quando encontram novidades literárias, como a que apresento. Pensando ouvir apenas estórias de satíricos e brincalhões ... elas não sentem o perigo das mulheres e dos sátiros".

Muito se falou sobre o Cândido, sobretudo na tese apresentada por Martin: "Trabalhemos sem arrazoar, este é o único meio de tornar a vida suportável". Mais famosa, ainda, a resposta de Cândido: "Bem dito, mas é preciso cultivar nosso jardim". Toda esta conversa liga-se ao diálogo de Luciano Hermotimus, no qual ressalta o agnosticismo, a atitude cética e satírica diante do "sério", tomado unilateralmente.

O tema do diálogo é a pretensão filosófica de possuir o melhor modo de vida, enquanto um cético aplica-se a demonstrar que tal gozo só pode ser o do homem comum. Os personagens são Licino, o cético, e Hermotimo, aprendiz estóico de sabedoria. Por que ler tantos livros, pergunta Licino a um apressado Hermotimo, sem tempo para a vida? Este responde com o aforismo hipocrático que ainda podemos encontrar no Fausto goetheano: "a vida é curta, a arte é longa". Vale a pena empalidecer lendo livros, escrevendo etc.? A cada uma destas perguntas, Hermotimo, como bom discípulo da filosofia dogmática, responde com uma citação célebre, cheia de lugares comuns. A insistência do cínico tem como resposta uma crítica de Hermotimo: você é contra a filosofia. "Eu não disse", responde Licino, "que não se deva estudar a filosofia, mas que devemos ser cuidadosos na escolha". Além do mais, continua bem adiante Licino, você esquece que as virtudes residem no agir justo e corajoso. “Todos vocês (por 'vocês' entendo os filósofos) negligenciam estas coisas, e estudam como encontrar e compor seus miseráveis textos, silogismos, problemas. Voces gastam a maior parte de suas vidas nisto, e todo aquele que vence esta corrida é o seu herói conquistador. É por tal motivo que vocês admiram os seus mestres, os velhos, porque eles reduzem seus discípulos à perplexidade e sabem como colocá-los na pior confusão". Em suma: "vocês esquecem a substância e caçam as sombras".

A corrida contra o tempo, a busca do saber e da vida feliz, a crença nos enunciados filosóficos e teológicos, tudo isto repete-se em Pangloss e na incansável ladainha do otimismo, deixando a ação eficaz em segundo plano. Tudo ocorre com os personagens do Cândido, nada é feito por 
eles. O fatalismo, que percorre as mentes e as espinhas de todos, com sua razão suficiente, prenuncia uma era onde os indivíduos e massas não agem, mas são agidos, não querem, mas são induzidos a querer, como bem descreve, para nossa época, Herbert Marcuse. Afinal, o sistema entrega a mercadoria. Mas é no Hermotimo de Luciano que Voltaire encontrou a arma para lutar contra Pascal, o seu inimigo de escol. "Nossa natureza está no movimento", dizia Pascal, "o repouso inteiro está na morte". Esta desgraça transforma-se, via Luciano, em benção. Os atos e não as sombras da morte constituem a virtude. Neste prisma, a frase de Cândido deixa de ser um quietismo filistino, como é a hermenêutica habitual, para se transformar em capacidade de vencer o Destino, promissor ou nefasto. A tolerância vem do saudável ceticismo, ele próprio não-absoluto, para o qual nenhum saber é definitivo, e para o qual ressalta a incongruência entre o real e as nossas forças intelectivas e morais.

O riso, em Pascal, demonstra desespero pela condição humana. Por isto, ele não entra na economia difícil de harmonização entre o sério e o cômico. Já Voltaire assume o polo oposto. É o que lemos nas Observações sobre os pensamentos de Pascal: "Quanto a mim, quando vejo Paris ou Londres, não vejo razão alguma para o desespero de que fala Pascal; vejo uma cidade que nada se parece a uma ilha deserta, mas que é povoada, opulenta, policiada, e onde os homens são felizes tanto quanto a natureza humana o permite. Qual é o homem sábio que se entregará ao desespero porque não conhece a natureza de seu pensamento, porque não conhece os atributos da matéria?". Contra Pascal, escreve Voltaire: “Minha grande disputa contra ele gira precisamente ao redor do fundamento de seu livro. Ele pretende que, para que uma religião seja verdadeira, é preciso que ela conheça a fundo a natureza humana, e que ela explique tudo o que se passa em nosso coração. Eu penso que não é deste modo que se deve examinar uma religião, o que é tratá-la como se fosse um sistema filosófico; penso que é preciso unicamente ver se esta religião é revelada ou não...".

Analisando a escrita de Pascal e de Voltaire, Leo Spitzer colhe esta diferença: "Pascal, o grande estilista, disse que, se fosse semelhante a Deus, o estilo não seria necessário. Voltaire, diferente de Pascal, mas escritor não menos soberbo, serve-se de seu estilo não para conduzir persuasivamente o homem até Deus, mas para compensar a solidão interior do homem sem Deus e para dar-lhe pelo menos o sentido do triunfo mental ... O ‘tempo' de Voltaire é a rapidez, a sua dimensão é a altitude, a sua lei, a liberdade do que é grave. Ele eleva o intelecto do homem não ao paraíso, mas ao céu" (Critica stilistica e semantica storica, Bari, Laterza, 1966). 
Deste modo, a tolerância trazida pela atitude cética, a qual separa natureza e revelação, dando à fé estatuto de fé, não a deixando imiscuirse no pensamento científico, político, artístico, é base da refutação de Pascal, melhor seria dizer, do cristianismo sócio-político, por parte de Voltaire. Sainte-Beuve cita a opinião de alguém que teria afirmado: "Supondo-se que Pascal tivesse sido filósofo, ele teria sido cético. Seu modo de raciocinar implica o ceticismo filosófico". Sim, objeta Sainte-Beuve, "mas Pascal sendo cristão e não filósofo, esta hipótese cai por si mesma". Este é o ponto de toda a nossa conversa, hoje. Se o cristianismo é revelado, e, portanto, não brota do mundo natural e humano, ele é alheio às especulações sobre o ser e o nada, o verdadeiro e o falso, o belo e o feio, o ético e o criminoso. Não existe filosofia cristã a ser imposta, via dogma, aos cérebros pensantes. O mesmo ocorre com as leis, a ética etc. Do mesmo modo, não é possível substituir ao cristianismo uma religião "racional", expulsando os cristãos do mundo. Toda pretensão de juntar as águas resulta num monstro ridículo, digno da sátira. É deste modo que Luciano descreve o itinerário de Peregrinus, sujeito que confundiu todos os elementos da cultura e que, na irônica caracterização de Diderot, "começou sendo adúltero, pederasta e parricida e acabou tornando-se cínico, cristão, apóstata, louco. A mais louvável ação de sua vida foi a de queimar-se vivo. Julgue-se as outras por ela".

Auerbach antipatiza com a escrita rápida de Voltaire, que aproxima traços distantes para explodir as conivências estabelecidas, como se elas fossem naturais. Mas esta aproximação de incongruências permite afastar, no campo da filosofia e da política, as ligações também julgadas naturais entre os mandamentos dos cristãos, válidos para eles apenas, e a ordem legal e a ratio studiorum das escolas. Sempre que uma crença revelada, isto é, não dependendo da racionalidade humana, exige para si o acolhimento universal, temos a intolerância que levanta fogueiras, prende os refratários, tortura os sacrílegos, censura os livros, demite os professores, impede a livre discussão. Pascal soube usar o riso contra os jesuítas, os filósofos e os políticos. Até aí, sua obra é notável. Mas quando pretende, via fé revelada, descer mais fundo do que a razão, ele deve ser combatido como fonte de intolerância e de fanatismo.

Tratando-se de um escritor conhecido como campeão da tolerância, precisamos ouvir um intolerante confesso, que fez disto virtude, Joseph De Maistre. Nunca o ódio pelas filosofias democráticas do século XVIII se manifestou mais violentamente do que nas páginas das Soirées de Saint-Petersbourg. Voltaire, segundo De Maistre, "sempre foi apenas gracioso (joli)". "Ele é encantador, dizem. Mas esta palavra, para mim, representa uma crítica". Continua o caridoso De Maistre, vestindo a máscara de personagem atrabiliário, o Conde: Voltaire é "medíocre, frio, e 
com freqüência (quem acreditaria?) pesado e grosseiro na comédia; pois o malvado nunca é cômico. Pela mesma razão, ele não soube fazer um epigrama ... se ensaia a sátira, ele escorrega para o libelo; ele é insuportável na história, apesar de sua arte, de suas elegâncias, de suas graças estilísticas; nenhuma qualidade pode substituir as que lhe faltam, a saber, a gravidade, a boa fé e a dignidade, as quais são a vida da história".

O leitor não está satisfeito? Então escute o que mais diz Joseph De Maistre sobre nosso escritor: "monotonia de sufocar plaina sobre a maior parte de seus escritos. Estes só têm dois assuntos: a Bíblia e seus inimigos. Ele blasfema ou insulta". O retrato de Voltaire serve, até hoje, para todos os inimigos da razão laica. "O seu riso" assevera De Maistre, "não é legítimo: trata-se de uma carantonha. Vocês não notaram que o anátema divino foi escrito em seu rosto? ... Olhem esta fronte abjeta que o pudor nunca enrubesceu, estas duas crateras apagadas onde parecem ainda borbulhar a luxúria e o ódio. Esta boca ... este rictus espantoso, de orelha a orelha, estes lábios pinçados pela cruel malícia, como uma espécie de mola prestes a se abrir para lançar blasfêmia e sarcasmo ... Voltaire, com seu aguilhão, belisca sem cessar as duas raízes da sociedade, as mulheres e os jovens; ele os embebe com seu veneno, o qual ele transmite de geração a geração". "Outros cínicos", diz mais adiante De Maistre, "apavoraram a virtude, Voltaire apavorou o vício". E por que não? Nosso filósofo é corrompido ao ponto de ter sido expulso da própria Sodoma...: "Sodoma o baniria...".

Terminemos lembrando as palavras, agora de um cristianíssimo poeta, importante em nosso tempo. "O método pascalino", diz T.S. Eliot, "no todo, é o método natural e correto para o cristão; e o método oposto é o assumido por Voltaire. Devemos recordar que Voltaire, na sua tentativa de refutar Pascal, deu, de uma vez por todas, o tipo para esta refutação ... Porque Voltaire apresentou, melhor do que ninguém até então, o ponto de vista do descrente; e no fim nós devemos escolher, para nós mesmos, entre um ponto de vista e o outro."

Os deuses de Luciano riram, no ocaso da cultura grega. O Deus pascalino riu, no crepúsculo da cultura cristã. Voltaire apenas continuou, agora do lado humano, a tarefa de escoimar, na vida espiritual, uma intolerância que era tanto maior, quanto menor era a fé coletiva na divindade e nos valores cristãos. Seus textos apresentam-se como Janus: neles, podemos gargalhar com as tolices religiosas, científicas, políticas, zombando de todos os fanatismos. Ao mesmo tempo, o riso nos conduz aos problemas mais graves da filosofia moral do ocidente, desde que tenhamos informações para ler os seus escritos em todas as suas facetas. O gênero sério-cômico ainda não foi re-assimilado, depois da seriedade especulativa do século XIX, pela nossa cultura. Talvez seja por isto que 
não sabemos afastar os fanatismos que se instalam na mídia eletrônica, nos comícios políticos, nos estádios de futebol, e "last but not least", nas igrejas, capelas, sinagogas e mesquitas de nossos dias. As guerras, as torturas, os atentados impunes aos direitos humanos - a começar com o direito à diferença - resultam desta perda da capacidade de rir. Comemorando os séculos de Voltaire, talvez possamos retomar a boa via aberta por Demócrito e realizada pela enorme fieira de pensadores que solaparam formas geladas do espírito, como Luciano, Erasmo, Rabelais, Voltaire, Diderot e todos os que definiram o valor e a beleza deste mundo, exorcizando o fanatismo que brota dos delírios causados pela sandice do "melhor dos mundos possíveis".

O tirano, sobretudo o que manipula a religião, pensa Voltaire, "deseja comandar tolos, e acredita que os burros obedecem melhor do que os demais". Quando os homens comuns acreditarem que a ignorância não paga a pena, e que as perseguições são abomináveis, surgirá uma opinião pública livre e tolerante (Dicionário filosófico, "preconceitos"). O supersticioso é governado pelo fanático e se torna fanático. A superstição é doença do espírito. O político conseguiria combatê-la? "Este problema é espinhoso, trata-se de perguntar até que ponto deve-se fazer uma punção num hidrópico. Ele pode morrer na mesa cirúrgica. Isto depende da prudência do médico. Se o número de supersticiosos diminuir num país, as inflações do fanatismo e das desgraças nele desaparecem. Estes são problemas perenes, até hoje enfrentados por nós. Como exemplo, temos a tortura. Sempre que existe asneira política, religiosa, acadêmica, há fanatismo e intolerância nas massas. Estas, por uma palha contra os preceitos estabelecidos, exigem que os desviantes sejam tratados "exemplarmente". (Cf. Dicionário filosófico, Tortura).

Tudo, nos tempos modernos, depende da seriedade. Parece que o mundo foi vencido pelo vírus hegeliano. Perdeu-se, com isto, a ponta crítica que lanceta as bobagens do Estado e dos civis, laicos ou religiosos. O homem, desde o século XVIII, cresceu em ciência e técnica, abafando o riso dos deuses e dos satíricos. O resultado encontra-se na tolice que aumenta em escala planetária, com seitas malucas e cultos aberrantes arrebanhando multidões. No Brasil, vencem as cacofonias dos que enganam a piedade popular e vampirizam a crendice das massas. Nas Américas pastores berram intolerância na mídia, espalham superstição, intoxicam almas. No Oriente e na África, regimes teocráticos deformam seres humanos em nome de um Deus sanguinário. Na Europa, o "neo" nazismo promove o retorno dos energúmenos racistas, apressando a morte do pensamento. Fanatismo é monomania, é querer impor aos muitos uma só visão, se preciso utilizando a força. A sátira racional, ao contrário, opera com muitas vozes, não necessariamente harmônicas. 
Como a democracia, a sátira inclui dissonâncias, e nisto reside a sua beleza. Além das sátiras de Voltaire, polifônicas na essência, $O$ sobrinho de Rameau, a partir de duas vozes, apresenta o coro múltiplo dos sábios e tolos de seu tempo, de sempre. Não é coincidência, se o fio condutor daquele texto reside na refutação, em ato, das teorias cartesianas ou pitagóricas do tio Rameau sobre o físico harmônico, o político harmônico etc. Assim também, como nota Jean Starobinski, as Cartas persas são regidas pela "pluralidade das consciências, pela diversidade dos pontos de vista e das convicções" (Exílio, sátira, tirania em Le remède dans le $m a l$ ). Com esta técnica, abriu-se o caminho para a liberdade moderna de pensamento, exorcizando-se o desejo milenar, enraizado nas almas despóticas, de impor o uníssono em todos os assuntos humanos. Entre o ideal do concanto, acarinhado por Santo Agostinho, e as hordas que entoaram hinos sobre um país acima de tudo, temos um intervalo musical, odiado pelo pretérito e pelo futuro, no século XVIII. Esta é a polifonia da razão. As forças arcaicas uniram-se contra ela, as fogueiras nazistas substituíram os autos da fé. Hoje retoma-se a nostalgia da unidade.

O sonho de Kant e de Saint-Pierre, a famosa união européia, mostra-se mais do que ambígua. Nela, os diferentes são perseguidos e expulsos. A fraternidade, a igualdade, a liberdade são monopólio dos brancos, nativos, deuses europeus. Enquanto isto, ruge o ódio à diferença no Oriente Médio. Os blocos, poderosos ou fracos, tendem a se alicerçar nos preconceitos e na superstição. As Luzes, mais do que nunca, tornam-se imperativo categórico de quem ainda não perdeu o siso. Tolerar a propaganda genocida não é tarefa democrática, mas covardia envergonhada e tola. Expandir o irracionalismo, a prevenção contra a ciência e a técnica, significa manter a divisão mundial entre os opulentos e os destinados a sofrer seu destino, sem remissão. Massas ignorantes constituem o solo fértil dos sofistas e charlatães. Quando indivíduos da classe média acreditam que falar muitas vezes a palavra dinheiro lhes traz o próprio, a culpa deve ser partilhada entre eles e o espertalhão, sócio lingüista ou quejandos, que, efetivamente, enche as burras e infesta as páginas e telas da mídia. Mas os universitários, cientistas, escritores que se calam por medo ou descaso assumem uma culpa bem mais importante neste cenário emburrecedor. Magos, gnomos, florais de Bach, toda esta enciclopédia antiga da loucura humana convive perfeitamente com o computador, com o telefone celular, com o fetiche tecnológico. Falta razão para perceber que estes instrumentos podem ampliar o espírito, ou comprimi-lo ao estatuto das amebas intelectuais.

O medo da impopularidade soma-se à demagogia e temos o falso pudor dos pensadores. A fala politicamente correta deixa impune o charlatanismo mais escandaloso. Os cérebros pensantes, em grande parte, são 
coniventes com as novas infâmias. Não se critica, nas rodas intelectuais, os milagreiros cujas anedotas fariam as delícias de Luciano, Rabelais, Erasmo, Voltaire, Diderot. Em plena São Paulo moderna já estão sendo vendidos, nos lucrativos escritórios das seitas, apartamentos paradisíacos. $\mathrm{O}$ seu preço aumenta se eles estiverem próximos à morada de Jesus Cristo. As chaves são entregues pelos pastores com honestidade, depois da fatura paga... Esta história, como a de Luciano, é verdadeira. Como é efetiva a ignorância em nosso país. Aqui, as universidades são asfixiadas criminosamente pelos governos e astrólogos norteiam as mentes incultas. No Brasil, quem não acredita em milagre perde eleições. Urge purificar a fé pública e imprimir os iluministas franceses. Antes de escurecer os cérebros dos estudantes com o lero-lero irracionalista, ponha-se diante de seus olhos a saudável irreverência das Luzes, a razão satírica que atenua a loucura séria do fanatismo.

ROMANO, R. Voltaire and the satire. Trans/Form/Ação (São Paulo), v.20, p.7-38, 1997.

- ABSTRACT: This paper stresses the relevance of Lucianic satire within the thought of the Enlightenment and, in particular, in Voltaire's works. At he same time, the typical lack of humour of contemporary philosophy is criticised from the standpoint of the comparative analysis of Enlightenment prose and the sibylline discourse of current irrationalist trends such as Martin Heidegger's and his followers'.

- KEYWORDS: Satire; humour; reason; empirical and transcendental.

\section{Referências bibliográficas}

BOMPAIRE, J. Lucien écrivain. Imitation et création. Paris, 1968.

BRAHAM, R. B. Unruly Eloquence, Lucian and the Comedy of Traditions. Cambridge: Harvard University Press, 1989.

BRANDÃO, J. L. Doente, doença, médicos e medicina em Luciano de Samósata. Cadernos de História e Filosofia da Ciência, Série 2, v. 2, n. 2, p. 145-64, 1990.

ELIOT, T. S. Selected Essays. London: Faber and Faber, 1980. 
HEGEL, G. W. F. Werk in Zwanzig Bänden. Frankfurt a.m.: Suhrkamp Verlag, 1975.

LUCIANO. Cambridge: Harvard University Press, Loeb Classical Library, 1972.

MATTIOLI, E. Luciano e l'Umanesimo. Napoli: Nella Sede dell' Instituto, 1980.

MAYER, C. A. Lucien de Samosate et la renaissance française. Genève, 1984.

PASCAL. L'oeuvre de Pascal. Paris: Gallimard, 1950, Chapel Hill, 1979.

PLUTARCO. Cambridge: Havard University Press, Loeb Classical Library, 1986.

ROBISON, C. Lucian and his influence in Europe. London: Chapel Hill, 1979.

SAINTE-BEUVE. Port-royal. Paris: Gallimard, 1962. 3v. (Edição Pleiade)

SCHENK, L. Lukian und die französische Literatus im Zeitalter der Aufklärang. München: Ludwig Maximilians Universität zu München, 1931.

VOLTAIRE, F. M. A. Oeuvres complètes. Paris: Garnier Frères, 1879. (Liechtenstein: Kraus Reprint Limited, 1967). 